Original Research Article

\title{
Anemia in pregnancy: a prospective study of 100 cases
}

\author{
Pereira E. ${ }^{1}$, Tambekar M. ${ }^{2}$ \\ ${ }^{1}$ Dr. Evith Pereira, Senior Resident, ${ }^{2}$ Dr. Manisha Tambekar, Associate Professor; both authors are attached with \\ Department of Pathology, MGM Medical College, Navi Mumbai.
}

Corresponding Author: Dr. Manisha Tambekar, Associate Professor, Department of Pathology, MGM Medical College, Navi Mumbai. E-mail: cdoctormanisha@gmail.com

\begin{abstract}
Background: Anemia in pregnancy is a major public health problem worldwide and is the most common hematological disorder during pregnancy. According to WHO, 35 to $75 \%$ of pregnant women in developing countries are anemic. Material and Methods: A prospective study was conducted among 100 pregnant women in their first trimester who attended antenatal clinic in a tertiary care hospital. Socio-demographic information were collected along with the blood samples. Hemoglobin concentration, blood indices, PCV, RDW, WBC and RBC counts were determined by a hematological auto-analyzer. Anemia was graded according to WHO criteria and morphological typing of anemia was done on the basis of peripheral blood smear examination. Result: A high prevalence (64\%) of anemia was observed among 100 pregnant women of which majority had mild anemia (50\%), moderate anemia (48.4\%) and severe anemia $(1.6 \%)$ commonly seen in younger age group (20-24 years). Factors such as age at marriage, age at first childbirth, illiteracy, gravida, working status, residence and socioeconomic status were found to be significantly. According to blood indices and peripheral blood smear analysis microcytic hypochromic anemia (59.4\%) was the commonest morphological type of anemia followed by dimorphic anemia (23.4\%). Iron deficiency anemia was found to be the commonest cause of anemia in pregnancy. Conclusion: The present study concluded that health education, good nutrition, thorough clinical and hematological examination with iron and folic acid supplements during antenatal period should be implemented to reduce the prevalence of anemia, thus decreasing maternal and fetal morbidity and mortality during pregnancy.
\end{abstract}

Keywords: Anemia, Pregnancy, Iron Deficiency, Sociodemographic factors, Hematology.

\section{Introduction}

Anemia is not a disease in itself, but a vital and sometimes lone indicator of an underlying pathology. Anemia and its manifestations or anemia complicating the course of another illness can bring the patients to medical attention. It is one of the most common disorder encountered during pregnancy. According to World Health Organization, $56 \%$ of all women living in the developing countries are anemic [1]. Prevalence of anemia in South Asian countries is among the highest in the world and India being the highest with $87 \%$ prevalence of anemia. According to the reports of World Health Organization, in developing countries, $35 \%$ to $75 \%$ of pregnant women and in the industrialized countries, $18 \%$ of women are anemic [2].

Anemia in pregnancy can be relative or absolute. Anemia can lead to varied maternal and fetal complications. Relative anemia is the normal

Manuscript received: $28^{\text {th }}$ September 2019

Reviewed: $6^{\text {th }}$ October 2019

Author Corrected: $14^{\text {th }}$ October 2019

Accepted for Publication: $18^{\text {th }}$ October 2019 physiological phenomenon that occurs in pregnancy due to larger increase in the plasma volume than in the red cell mass which results in the well-known physiological anemia of pregnancy. Absolute anemia involves a true decrease in the red cell mass, involving increased red cell destruction as in hemoglobinopathy, malaria and bacterial infection like urinary tract infection, increased red cell loss as in bleeding or decreased red cell production as in nutritional deficiency or chronic disease. There are many predisposing factors to anemia in pregnancy and these factors can be efficiently managed by increasing the knowledge and awareness about prevalence and prevention of anemia.

The predisposing factors being younger age group, grand multiparity, low socioeconomic status, illiteracy, ignorance, shorter intervals between two consecutive pregnancy. The iron stores depletion, malabsorption and inhibition of appetite can be caused by infection with hookworm and intestinal helminths as they lead to gastrointestinal blood loss causing micronutrient

Pathology Update: Tropical Journal of Pathology \& Microbiology Available online at: www.medresearch.in 790 | P a g e 


\section{Original Research Article}

deficiency and maternal anemia $[3,4]$. The effects on maternal health includes increased weakness, lack of energy, fatigue, poor work performance, palpitations, tachycardia, breathlessness, increased cardiac output, cardiac failure, pre-term labour, pre-eclampsia, sepsis and maternal death while effects on fetus includes preterm babies, small for gestational age and increased perinatal mortality rates [1].

\section{Materials and Methods}

The present study "Anemia in pregnancy: A prospective study of 100 cases" was carried out in the Central Laboratory (Hematology) of a tertiary care hospital, MGM Hospital, Kamothe and Kalamboli, Navi Mumbai carried out over a period of 2 years. Ethical committee approval was obtained prior to the commencement of the study

Sample size: A prospective study of 100 pregnant women attending antenatal clinic in their first trimester in a tertiary care hospital.

\section{Inclusion criteria:}

Pregnant women age $\geq 18$ years attending ANC clinic during first trimester.

\section{Exclusion criteria}

Diagnosed cases of anemia on treatment

History of recent blood transfusion

The clinical details were obtained from the ANC files and from the Central Laboratory requisition forms accompanying the blood samples. A detailed clinical history and physical examination was performed in each case. A structured questionnaire was used to collect the required data and information with the help of treating obstetrician. The detailed history, clinical and physical examination and hematological investigations were performed after seeking informed written consent from the patient. The socioeconomic status of the patient was calculated by using Revised Modified BG Prasad socioeconomic classification scale, 2016.

A total of 100 random cases were studied fulfilling the criteria of pregnant women in their first trimester of pregnancy. Detailed history was taken and recorded in proforma. Blood counts were done by a 3part differential automated cell analyzer $(\mathrm{kx} 21)$ followed by peripheral smear examination. Differential count and red cell morphology were done manually by staining the blood smears with Field's and Leishman's stain.

Following Investigations Were Carried Out: Hemoglobin, RBC count, WBC count, Platelet count, Hematocrit, Red cell indices, RDW, Peripheral blood smear examination, Reticulocyte count, Serum B12, Serum Ferritin, Serum iron studies, HPLC

Sample collection: $2 \mathrm{ml}$ of blood was collected by venepuncture under aseptic precautions in a dry tube containing ethylene di-amine tetra acetic acid (EDTA) anticoagulant for hematological investigations and $5 \mathrm{ml}$ of blood was collected in plain bulb for additional immunoassay investigations.

Samples were processed by 3 parts differential automated cell analyser (Sysmex Kx21) and blood counts with other hematological parameters were obtained. The biochemical investigations and HPLC were performed on Access 2 and D10 in the cases where it was required to confirm the cause of anemia. Prevalence of anemia was expressed in percentage and Chi square test was used as a test of significance. $\mathrm{P}$ value of 0.005 and less was considered as statistically significant.

Peripheral smear study: Once the blood films were prepared from fresh EDTA - anti-coagulated and stained with Field's and Leishman's stains.

\section{Results}

Out of total 100 Pregnant women, 64 were anemic and 36 Non-anemic. The most common affected age group was 20-24 years in both anemic $(48.4 \%)$ and non-anemic $(44.4 \%)$. The maximum pregnant women (54) at the time of marriage were in the age group of 20-24 years. Anemic pregnant women (23) at the time of first childbirth were in the age group of 2024 years. Anemia was commonly observed in primigravida in the age group of 20-24 years (18 cases) and multigravida in the age group of 25-29 years (14 cases). Mild type of anemia was observed in multigravida (10 cases each) in age groups 20-24 years and 25-29 years as compared to primigravida ( 07 cases) in 20-24 years age group and Moderate type of anemia was commonly seen in primigravida (11 cases) in age group 20-24 years than multigravida ( 8 cases) in age group of $\geq 30$ years category. Out of the total 64 anemic cases, $50 \%$ were of mild, $48.4 \%$ moderate and $1.6 \%$ severe category. The peripheral blood smear examination showed microcytic hypochromic picture in $59.4 \%$ cases followed by Dimorphic in $18.8 \%$ and Normocytic Normochromic in $15.6 \%$ cases. Out of total 100 Pregnant women, 64 were anemic and 36 Non-anemic. The most common affected age group is 20-24 years in both anemic (48.4\%) and non-anemic (44.4) (Table 1).

Pathology Update: Tropical Journal of Pathology \& Microbiology Available online at: www.medresearch.in 791 | P a g e 
Original Research Article

Table-1: Prevalence / Incidence of anemic and non-anemic pregnant women according to age groups.

\begin{tabular}{|c|c|c|c|}
\hline Age group (Years) & Anemic & Non-anemic & Total \\
\hline$<20$ & $03(4.7 \%)$ & $03(8.3 \%)$ & 06 \\
\hline $20-24$ & $31(48.4 \%)$ & $16(44.4 \%)$ & 47 \\
\hline $25-29$ & $18(28.1 \%)$ & $08(22.3 \%)$ & 26 \\
\hline$\geq 30$ & $12(18.8 \%)$ & $09(25 \%)$ & $\mathbf{1 0 0}$ \\
\hline Total & $\mathbf{6 4}$ & $\mathbf{3 6}$ & $\mathbf{1 0 0}$ \\
\hline
\end{tabular}

The maximum women (34) at the time of marriage were in the age group of 20-24 years. Since p-value is $<0.05$, it was statistically significant (Table 2).

Table-2: Distribution of anemic pregnant women according to age at marriage.

\begin{tabular}{|c|c|c|c|}
\hline Age group (years) & Anemic $(\mathbf{n}=\mathbf{6 4})$ & Percentage (\%) & p- value \\
\hline$<20$ & 21 & 32.8 & \multirow{2}{*}{$<0.05$} \\
\hline $20-24$ & 34 & 53.1 \\
\hline $25-29$ & 7 & 10.9 \\
\hline Total & 2 & 3.1 & \\
\hline
\end{tabular}

The maximum anemic pregnant women (23) at the time of first childbirth were in the age group of $20-24$ years. Since pvalue is $<0.05$, it was statistically significant (Table 3 ).

Table-3: Distribution of anemic pregnant women according to age at first childbirth.

\begin{tabular}{|c|c|c|c|}
\hline $\begin{array}{c}\text { Age group } \\
\text { (years) }\end{array}$ & $\begin{array}{c}\text { Number of anemic pregnant } \\
\text { women }(\mathbf{n}=\mathbf{3 5})\end{array}$ & $\begin{array}{c}\text { Percentage } \\
(\%)\end{array}$ & p-value \\
\hline$<20$ & 6 & 17.1 & \multirow{2}{*}{$<0.005$} \\
\hline $20-24$ & 23 & 65.8 & \\
\hline $25-29$ & 6 & 17.1 & \\
\hline
\end{tabular}

Table-4: Demographic variables of anemic and non-anemic pregnant women.

\begin{tabular}{|c|c|c|c|c|c|}
\hline \multirow[t]{2}{*}{ S.No } & \multirow[t]{2}{*}{ Variables } & \multicolumn{2}{|c|}{ Number of pregnant women $(n=100)$} & \multirow[t]{2}{*}{ Total } & \multirow[t]{2}{*}{ P value } \\
\hline & & Anemic & Non-anemic & & \\
\hline \multirow[t]{6}{*}{1} & \multicolumn{5}{|l|}{ Education } \\
\hline & Non- literate & 05 & 02 & 7 & \multirow{5}{*}{0.705} \\
\hline & Below 10th & 20 & 09 & 29 & \\
\hline & 10th grade to below graduation & 24 & 16 & 40 & \\
\hline & Graduate & 13 & 06 & 19 & \\
\hline & Post- graduate & 02 & 03 & 5 & \\
\hline \multirow[t]{3}{*}{2} & \multicolumn{5}{|l|}{ Working Status } \\
\hline & Housewives & 61 & 29 & 90 & \multirow[b]{2}{*}{$0.018 *$} \\
\hline & Working & 03 & 07 & 10 & \\
\hline \multirow[t]{3}{*}{3} & \multicolumn{5}{|l|}{ Gravidity } \\
\hline & Primigravida & 28 & 19 & 47 & \multirow[b]{2}{*}{0.385} \\
\hline & Multigravida & 36 & 17 & 53 & \\
\hline \multirow[t]{3}{*}{4} & \multicolumn{5}{|l|}{ Residence } \\
\hline & Urban & 10 & 12 & 22 & \multirow[b]{2}{*}{$0.04^{*}$} \\
\hline & Rural & 54 & 24 & 78 & \\
\hline \multirow[t]{3}{*}{5} & \multicolumn{5}{|l|}{ Type of Family } \\
\hline & Nuclear Family & 27 & 12 & 39 & \multirow[b]{2}{*}{0.302} \\
\hline & Joint Family & 36 & 25 & 61 & \\
\hline \multirow[t]{4}{*}{6} & \multicolumn{5}{|l|}{ Socioeconomic Status } \\
\hline & Upper Class & 0 & 2 & 2 & \multirow{3}{*}{$0.041^{*}$} \\
\hline & Middle Class & 59 & 34 & 93 & \\
\hline & Lower Class & 5 & 0 & 5 & \\
\hline
\end{tabular}

*Socioeconomic status, Residence and Working status are showing p- value $<0.05$, Hence it is statistically significant. 


\section{Original Research Article}

Table 4 represented the various demographic variable such as education, working status, gravidity, residential background, type of family, and socioeconomic status in anemic and non-anemic pregnant women.

Mild type of anemia was commonly observed in multigravida (10 cases each ) in age groups 20-24 years and 25-29 years as compared to primigravida (07 cases) in 20-24 years age group and Moderate type of anemia was commonly seen in primigravida ( 11 cases) in age group 20-24 years than multigravida ( 8 cases) in age group of $\geq 30$ years (Table 5).

Table-5: Distribution of gravida types according to grading of anemia.

\begin{tabular}{|c|c|c|c|c|c|c|}
\hline \multirow{2}{*}{\begin{tabular}{c}
\multirow{2}{*}{$\begin{array}{c}\text { gge } \\
\text { (years) }\end{array}$} \\
\cline { 2 - 7 }
\end{tabular}} & \multicolumn{2}{|c|}{ Mild } & \multicolumn{2}{c|}{ Moderate } & \multicolumn{2}{c|}{ Severe } \\
\cline { 2 - 7 } & $\begin{array}{c}\text { Primi- } \\
\text { gravida }\end{array}$ & $\begin{array}{c}\text { Multi- } \\
\text { gravida }\end{array}$ & $\begin{array}{c}\text { Primi- } \\
\text { gravida }\end{array}$ & $\begin{array}{c}\text { Multi- } \\
\text { gravida }\end{array}$ & $\begin{array}{c}\text { Primi- } \\
\text { gravida }\end{array}$ & Multi-gravida \\
\hline$<20$ & 02 & 0 & 01 & 00 & 0 & 0 \\
\hline $20-24$ & 07 & 10 & 11 & 02 & 0 & 1 \\
\hline $25-29$ & 01 & 10 & 03 & 04 & 0 & 0 \\
\hline$\geq 30$ & 01 & 1 & 02 & 08 & 0 & 0 \\
\hline Total & $\mathbf{1 1}$ & $\mathbf{2 1}$ & $\mathbf{1 7}$ & $\mathbf{1 4}$ & $\mathbf{0}$ & $\mathbf{1}$ \\
\hline
\end{tabular}

Out of the total 64 anemic cases, $50 \%$ are of mild category, $48.4 \%$ moderate and $1.6 \%$ severe. Highest number of cases of all three categories are seen in 20-24 years age group (Table 6).

Table-6: Age group wise grading of anemia on the basis of hemoglobin levels.

\begin{tabular}{|c|c|c|c|}
\hline $\begin{array}{c}\text { Age group } \\
\text { (years) }\end{array}$ & $\begin{array}{c}\text { Mild } \\
\mathbf{( 1 0 - 1 0 . 9 g / d l )}\end{array}$ & $\begin{array}{c}\text { Moderate } \\
\mathbf{( 7 . 1 - 9 . 9} \mathbf{g} / \mathbf{d l})\end{array}$ & Severe (<7g/dl) \\
\hline$<20$ & 02 & 01 & -- \\
\hline $20-24$ & 17 & 13 & 01 \\
\hline $25-29$ & 11 & 07 & -- \\
\hline$\geq 30$ & 02 & 10 & -- \\
\hline Total & $\mathbf{3 2} \mathbf{( 5 0 \% )}$ & $\mathbf{3 1} \mathbf{( 4 8 . 4 \% )}$ & $\mathbf{0 1}(\mathbf{1 . 6 \% )}$ \\
\hline
\end{tabular}

Comparison of the hematological profile of anemic and non-anemic pregnant women was documented in Table 7. Hemoglobin, Hematocrit, MCV, MCH, MCHC indicated significant difference between the average values of anemic and non-anemic pregnant women for these above-mentioned parameters.

Table-7: Comparison of hematological profile of anemic and non-anemic pregnant women.

\begin{tabular}{|l|c|c|c|}
\hline Hematological Parameters & Anemic & Non-anemic & p - value \\
\hline Hb (g/dl) & $9.61 \pm 1.07$ & $12.06 \pm 0.71$ & 0.00 \\
\hline Hct (\%) & $31.13 \pm 2.81$ & $35.88 \pm 2.11$ & 0.00 \\
\hline RBC Count (mill/cmm) & $4.14 \pm 0.59$ & $4.34 \pm 0.42$ & 0.08 \\
\hline MCV (fl) & $75.56 \pm 9.85$ & $83.44 \pm 5.64$ & 0.00 \\
\hline MCH (pg) & $23.75 \pm 4.22$ & $27.99 \pm 2.53$ & 0.00 \\
\hline MCHC (g/d) & $31.08 \pm 1.81$ & $33.48 \pm 1.18$ & 0.00 \\
\hline RDW (\%) & $44.66 \pm 4.78$ & $42.89 \pm 3.99$ & 0.063 \\
\hline WBC Count (cells/cmm) & $8,551.56 \pm 2,265.83$ & $7,877.78 \pm 1,590.53$ & 0.12 \\
\hline
\end{tabular}

${ }^{*}$ p- value $<0.05$

The commonest red cell morphology on peripheral blood smear was Microcytic Hypochromic (59.4\%) followed by Dimorphic (NN+MH) (18.8\%) and Normocytic Normochromic (15.6\%) (Table 8). 


\section{Original Research Article}

Table-8: Red cell morphology on peripheral blood smear of anemic pregnant women.

\begin{tabular}{|l|c|c|}
\hline RBC morphology on peripheral blood smear & Number of pregnant women & Percentage \\
\hline Normocytic Normochromic (NN) & 10 & 15.6 \\
\hline Microcytic Hypochromic (MH) & 38 & 59.4 \\
\hline Macrocytic (Mac) & 1 & 1.6 \\
\hline Dimorphic & \multicolumn{2}{|c|}{} \\
\hline A) Normocytic Normochromic+ Microcytic Hypochromic & 3 & 18.8 \\
\hline B) Microcytic Hypochromic + Macrocytic & $\mathbf{6 4}$ & 4.6 \\
\hline Total & $\mathbf{6 4}$ & $\mathbf{1 0 0}$ \\
\hline
\end{tabular}

In moderate grade of anemia, the predominant morphological type of anemia was microcytic hypochromic anemia, $\mathrm{p}$ value was statistically significant (Table 9).

Table-9: Comparison of grade of anemia with morphological type of anemia.

\begin{tabular}{|c|c|c|c|c|c|}
\hline $\begin{array}{c}\text { Grade of } \\
\text { anemia }\end{array}$ & $\begin{array}{c}\text { Microcytic } \\
\text { hypochromic }\end{array}$ & Macrocytic & Dimorphic & $\begin{array}{c}\text { Normocytic } \\
\text { normochromic }\end{array}$ & p -value \\
\hline Mild & 15 & 01 & 6 & 10 & 0 \\
\hline Moderate & 23 & 00 & 8 & 0 & 0.011 \\
\hline Severe & 0 & 00 & 1 & 10 \\
\hline Total & 38 & 01 & 15 & 0 \\
\hline
\end{tabular}

\section{Discussion}

Anemia is one of the major and important health problems among pregnant women in the world. It affects $25-50 \%$ of the population of the world and approximately 50\% of pregnant women. Anemia in pregnancy accounts for one-fifth of maternal death worldwide.

Table-10: Comparison of prevalence rate of anemia in different studies.

\begin{tabular}{|l|c|c|c|c|}
\hline Authors & Country & Year & Number of cases & Prevalence Rate \\
\hline Lokare et al [5] & India & 2012 & 352 & $87.2 \%$ \\
\hline Viveki et al [6] & India & 2012 & 228 & $82.9 \%$ \\
\hline Saraswathi et al [7] & India & 2013 & 9642 & $51 \%$ \\
\hline Rao et al [8] & India & 2013 & 104 & $93.26 \%$ \\
\hline Ullah et al [9] & Pakistan & 2013 & 210 & $67.6 \%$ \\
\hline Naz et al [10] & Pakistan & 2013 & 810 & $54.3 \%$ \\
\hline Bivalkar et al [11] & India & 2014 & 150 & $43.4 \%$ \\
\hline Vemulapalli et al [12] & India & 2014 & 986 & $100 \%$ \\
\hline Mahashabde et al [13] & India & 2014 & 300 & $63 \%$ \\
\hline Morsy et al [14] & Egypt & 2014 & 400 & $91.25 \%$ \\
\hline Gedefaw et al [15] & Ethiopia & 2014 & 363 & $41.8 \%$ \\
\hline Anjum et al [16] & Pakistan & 2015 & 100 & $75 \%$ \\
\hline Suryanarayana et al [17] & India & 2015 & 446 & $64 \%$ \\
\hline Manjulatha et al [18] & India & 2015 & 1000 & $99 \%$ \\
\hline Manglaet al [19] & India & 2016 & 850 & $98 \%$ \\
\hline Siddalingappa et al [20] & India & 2016 & 314 & $62.4 \%$ \\
\hline Prashant et al [21] & India & 2017 & 291 & $\mathbf{1 0 0}$ \\
\hline Present Study & India & $\mathbf{2 0 1 7}$ & $\mathbf{6 4 \%}$ \\
\hline
\end{tabular}




\section{Original Research Article}

Table-11: Comparison of age group and severity of anemia in different studies.

\begin{tabular}{|l|c|c|c|c|c|}
\hline \multirow{2}{*}{ Studies } & \multirow{2}{*}{ Year } & \multirow{2}{*}{$\begin{array}{c}\text { Age Group } \\
\text { (years) }\end{array}$} & \multicolumn{3}{|c|}{ Severity of Anemia (\%) } \\
\cline { 5 - 6 } & & Mild & Moderate & Severe \\
\hline Shah et al [22] & 2012 & $20-25$ & 18 & 58 & 23.52 \\
\hline Lokare et al [5] & 2012 & $20-24$ & 24.7 & 54.5 & 7.9 \\
\hline Naz et al [10] & 2013 & $31-35$ & 23.18 & 37.7 & 39.09 \\
\hline Kefiyalew et al [23] & 2014 & $18-26$ & 55 & 32.5 & 12.5 \\
\hline Kefyalew et al [24] & 2014 & $26-30$ & 28.9 & 26.7 & 1.2 \\
\hline Morsy et al [14] & 2014 & $26-35$ & 27.5 & 28.5 & 35.25 \\
\hline Mahashabde et al [13] & 2014 & $20-24$ & 41.87 & 48.40 & 3.72 \\
\hline Vemulapalli et al [12] & 2014 & $21-25$ & 52.73 & 40.97 & 6.2 \\
\hline Bhise M. [25] & 2014 & $20-24$ & 30.38 & 58.59 & 11.03 \\
\hline Anjum et al [16] & 2015 & $17-30$ & 24 & 33 & 18 \\
\hline Suryanarayana et al [17] & 2016 & $21-25$ & 27 & 34 & 3 \\
\hline Rawat et al [26] & 2016 & - & 35.1 & 51.3 & 13.4 \\
\hline Mangla et al [19] & 2016 & $15-19$ & 41.76 & 37.05 & 19.17 \\
\hline Bano et al [27] & 2016 & $20-25$ & 28 & 43.4 & 7.2 \\
\hline Prashant et al [21] & 2017 & $20-29$ & 33 & 37 & 2 \\
\hline Pawale et al [28] & 2017 & $21-25$ & 16.5 & 67.75 & 15.75 \\
\hline Present Study & $\mathbf{2 0 1 7}$ & $\mathbf{2 0 - 2 4}$ & $\mathbf{5 0}$ & $\mathbf{4 8 . 4}$ & $\mathbf{1 . 6}$ \\
\hline
\end{tabular}

Anemia prior to and during pregnancy can remarkably influence maternal health as well as child's health [29]. The diagnosis of anemia during antenatal visit is very essential as it can help to institute intervention at an early stage thus preventing the complications of anemia and decreasing the maternal and perinatal mortality.

The present study included 100 pregnant women in their first trimester. The main aim was to assess the prevalence / incidence of anemia in pregnant women. In India the prevalence of anemia among pregnant women is about $65-75 \%$ [19].

In the present study on the basis of hemoglobin level of 100 pregnant women who were randomly selected, $64 \%$ pregnant women were anemic and 36\% non-anemic. The prevalence rate (64\%) of anemia in the present study was similar to the study conducted by Suryanarayana et al [17] in 2015. The prevalence of anemia in the present study was closer to the studies done by Siddalingappa et al [21], Mahashabde et al [13] and Ullah et al [9] which was 62.4\%, 63\% and 67.6\% respectively (Table 10). Prevalence of anemia in pregnancy varies from one region to another as well as from country to country. The factors contributing to high prevalence of anemia may be low dietary iron and folic acid intake or chronic blood loss owing to infections. In India, the other factors attributing to high prevalence of anemia in pregnancy includes early marriage, teenage pregnancy, less birth spacing, multiple pregnancies, phytate rich Indian diet and worm infestations $[29,30]$.

Age: In the present study, the age of the pregnant women ranged from 19-35 years where the mean age was 25-35 years. The most common affected age group in both anemic and non-anemic pregnant women was $20-24$ years $(48.4 \%$ anemic \& 44.4\% non - anemic) followed by $25-29$ years (28.1\% anemic \& $22.3 \%$ non- anemic) (Table 1$)$. This finding was similar to findings observed by Lokare et al [5], Mahashabde et al [13] and Bhise M [25]. The comparison of age group and severity of anemia in different studies was documented in Table 11.

Age at marriage: Prevalence of anemia among pregnant women who got married below 20 years and between $20-24$ years was $32.8 \%$ and $53.1 \%$ respectively (Table 2). Tembhare et al [31], in their study showed prevalence of $76 \%$ in the age group of 20-25 years and 19\% in age group less $<20$ years. However, they also stated that the percentage of severe anemia was high in pregnant women who got married $<20$ years of age. Bora et al [32] in his study showed similar (59.8\%) prevalence of anemia among pregnant women who got married below 18 years of age. The association between the age at marriage and prevalence of anemia in pregnancy was found to be statistically significant in the age group 2024 years ( $p$-value $<0.05$ ) as compared to other studies [20].

Pathology Update: Tropical Journal of Pathology \& Microbiology Available online at: www.medresearch.in 795 | P a g e 


\section{Original Research Article}

Age at first childbirth: In this study the prevalence of anemia (65.8\%) was high in those whose age at first childbirth was between 20-24 years (Table 3). Study done by Bora et al [32] also showed that pregnant women whose age at first childbirth was $<21$ years had higher prevalence of anemia (55.72\%). Age at first child birth can have detrimental effect on maternal as well as infant health. In this study the association between the age at first childbirth and prevalence of anemia in pregnancy was found to be statistically significant in the age group 20-24 years ( $\mathrm{p}$-value $<0.05$ ) as compared to other studies which showed no significance.

Education: Out of 64 anemic pregnant women, 92.2\% $(n=59)$ were literate whereas $7.8 \%(n=5)$ were illiterate (Table 4). Among the educated pregnant women, higher prevalence of anemia was seen among those whose education levels were below $10^{\text {th }}$ standard $(68.9 \%)$. The prevalence of anemia was less $(40 \%)$ among postgraduate pregnant women. This shows that with rise in the level of education the prevalence of anemia can be reduced.

Socio-economic status, residence and working status of pregnant women: It was observed that the prevalence of anemia was more in women belonging to lower socio-economic group (100\%), housewives (67.8\%) and those residing in rural areas (69.2\%) (Table 4). Many authors have stated that as the socioeconomic status decreases the prevalence of anemia also increases. It was observed that a strong association between socioeconomic status and anemia in pregnancy existed and was statistically significant $(\mathrm{p}=<0.041)$. Association was seen between area of residence (rural) and maternal anemia which was also statistically significant $(\mathrm{p}=0.04)$. Another study also showed high prevalence in rural area $(81 \%)$ as compared to urban area (51\%) [30].

Gravidity: Out of 100 cases, $53 \%$ were multigravida and $47 \%$ were primigravida. The prevalence of anemia in the present study was more in multigravida (67.9\%) as compared to primigravida (59.6\%) (Table 4). This study showed relatively less association between gravidity and maternal anemia. In studies done by Siddalingappa et al [20] and Kundap et al [30] they observed prevalence of anemia to be higher in multigravida $65 \%$ and $55 \%$ as compared to primigravida $60 \%$ and $45 \%$ respectively.

According to WHO Anemia in pregnancy is classified on the basis of hemoglobin levels into mild Anemia (10 -10.9 $\mathrm{g} / \mathrm{dl})$, moderate anemia $(7-9.9 \mathrm{~g} / \mathrm{dl})$ and severe anemia $(<7 \mathrm{~g} / \mathrm{dl})$. In the present study the prevalence of mild, moderate and severe anemia was $50 \%, 48.4 \%$ and $1.6 \%$ respectively (Table 5). Thus, the prevalence of anemia was little higher in mild type as compared to moderate type of anemia which was comparable to the study done by Vemulapalli et al [12] and Kefiyalew et al [23]. Prevalence of moderate anemia (48.4\%) in the present study was similar to the study done by Mahashabde et al [13]. In different studies the prevalence of moderate anemia ranged from $26.7 \%$ to $67.7 \%$ (Table 11), whereas the prevalence of severe anemia was $1.6 \%$ which was very close to the studies done by Kefyalew et al [24] $(1.2 \%)$ and Prashant D. et al [21] (2\%).

Grading of anemia age wise: The commonest age group to be affected in mild and moderate anemia was 20-24 years (Table 6), which was similar to the study done by Bhise M [25]. A longitudinal observational study conducted in Haryana showed higher prevalence of mild anemia in age group 20-24 years (61.34\%), while moderate anemia was seen in 25-29 years age group (48\%) and severe was seen in 15-19 years age group (64.6\%) [18].

Hematological profile: The overall mean hemoglobin was found to be $9.61 \pm 1.07 \mathrm{~g} / \mathrm{dl}$ with a range from 6-13.4 $\mathrm{g} / \mathrm{dl}$. In this study 36 pregnant women had normal range of hemoglobin. Das et al [33] observed mean hemoglobin of $9 \pm 1.5 \mathrm{~g} / \mathrm{dl}$ which is very close to our finding. It was observed the mean values of MCV, MCH and MCHC to be $75.56 \pm 9.85$, $23.75 \pm 4.22,31.08 \pm 1.81$ respectively (Table 7). The study done by Demmuouche et al [34] showed similar mean MCV of $75.70 \pm 10.48$, whereas the mean MCHC was $33.75 \pm 2.79$. In this study $51 \%$ of the pregnant women had MCV values $<$ $80 \mathrm{fl}$ suggesting microcytic anemia, $48 \%$ had between $80-100 \mathrm{fl}$ whereas only one case showed MCV $>100 \mathrm{fl}$ suggesting macrocytic anemia. There was statistically significant correlation between MCV, MCH and MCHC levels in anemic and non-anemic pregnant women $(\mathrm{p}=<0.005$, Table 7$)$.

In this study, overall $\mathrm{MCV}, \mathrm{MCH}$ and $\mathrm{MCHC}$ levels were low in 51\%, 58\% and 15\%, normal levels of MCV, $\mathrm{MCH}$ and MCHC were seen in $48 \%, 40 \%$ and $84 \%$ while high levels $1 \%, 2 \%$ and $1 \%$ of pregnant women respectively. The study done by Anjum et al [16] also showed high number of pregnant women with normal levels of MCHC (66 pregnant women). In this study there was increase number of cases with low levels of MCV and $\mathrm{MCH}$ which were in contrary to the findings seen by Anjum et al [16] where increased number of cases of normal levels of MCV and MCH were seen.

Pathology Update: Tropical Journal of Pathology \& Microbiology Available online at: www.medresearch.in 796 | P a g e 


\section{Original Research Article}

Red cell morphology: On peripheral blood smear examination, anemia was classified into microcytic hypochromic, macrocytic, normocytic normochromic, and dimorphic anemia. Maximum cases of microcytic hypochromic (59.4\%), followed by dimorphic (23.4\%), normocytic normochromic (15.6\%) and macrocytic (1.6\%) (Table 8) were also observed. These findings were consistent with, findings observed by Rawat et al [26] (51\%), Bivalkar et al [11] (55.4\%) and Pawale et al [28] (89.75\%). The commonest cause of anemia in pregnancy according to the WHO report is nutritional i.e. iron deficiency. In the present study, it showed microcytic hypochromic anemia to be the most predominant type of morphological anemia. Though IDA is the commonest cause of microcytic hypochromic anemia one should also rule out thalassemia. In thalassemia the RDW is not increased, RBC count is more than $5 \mathrm{mill} / \mathrm{cmm}$ with a microcytic hypochromic blood picture, iron stores are increased and $\mathrm{HbA} 2 \geq 4 \%$. In the present study the pregnant women with hemoglobin levels $<9 \mathrm{~g} / \mathrm{dl}$ were further investigated wherein biochemical parameters were studied for confirmation of iron deficiency. In this study, total 4 cases showed Mentzer index $<12$ and they further underwent hemoglobin electrophoresis to rule out thalassemia. However, no case of thalassemia was seen in this study.

Comparison of grade of anemia with morphological type: The second commonest morphological type of anemia was dimorphic anemia (23.4\%) whereas other studies done by Pawale et al [28] and Rawat et al [26] showed lesser percentage of $1.75 \%$ and $13 \%$ respectively. Least percentage (1.6\%) of macrocytic type of anemia was observed which was similar to the other studies wherein the prevalence was 4\% [26]. On correlating grade of anemia with morphological types of anemia, the moderate and mild grade of anemia were predominantly microcytic hypochromic morphologically whereas the severe anemia showed dimorphic blood picture $(\mathrm{p}=0.011$, statistically significant, Table 9$)$. In iron deficiency anemia besides microcytic hypochromic blood picture, mild to moderate poikilocytosis, pencil or cigar shaped cells, tear drop cells, ring cells and target cells can also be observed which can help us to differentiate between various causes of microcytic hypochromic anemia (Figure $1 \& 2$ ). Target cells are commonly seen in patients with thalassemia. In macrocytic anemia along with macro-ovalocytes, basophilic stippling, howell jolly body and hyper-segmented neutrophils can help us to reach a diagnosis (Figure 3). The biochemical parameters were also performed where in it was observed that the levels were decreased in all the cases. Studies done by other authors suggest serum ferritin to be a better biochemical parameter and its levels were seen reduced in their studies [1].

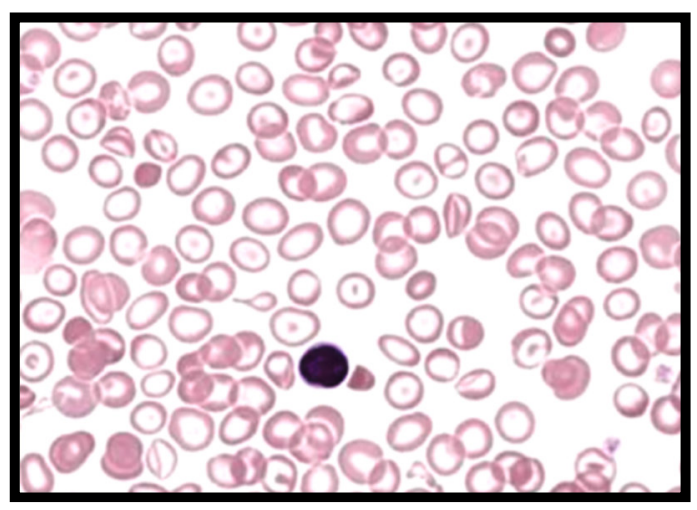

Figure 1: Iron deficiency anemia - microcytic hypochromic red blood cells with target cells (arrow) (field's stain, 1000x).

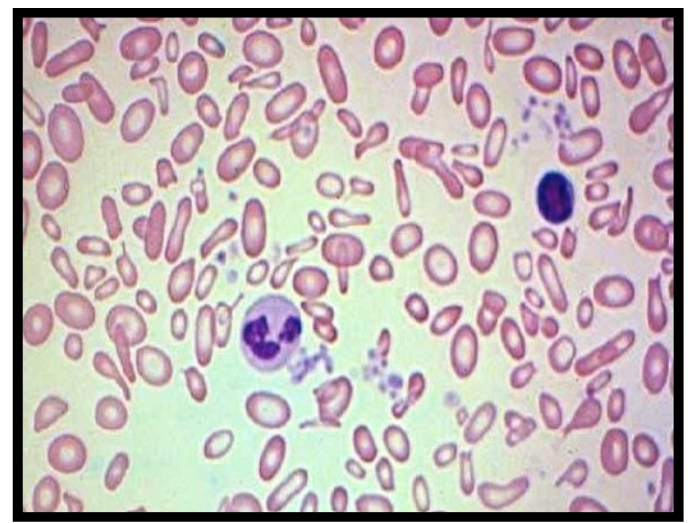

Figure 2: Iron deficiency anemia - microcytic hypochromic red blood cells with marked anisopoikiloctosis, tear drop cells and thin elongated pencil cells (field's stain, 1000x).

Pathology Update: Tropical Journal of Pathology \& Microbiology Available online at: www.medresearch.in 797 | P a g e 


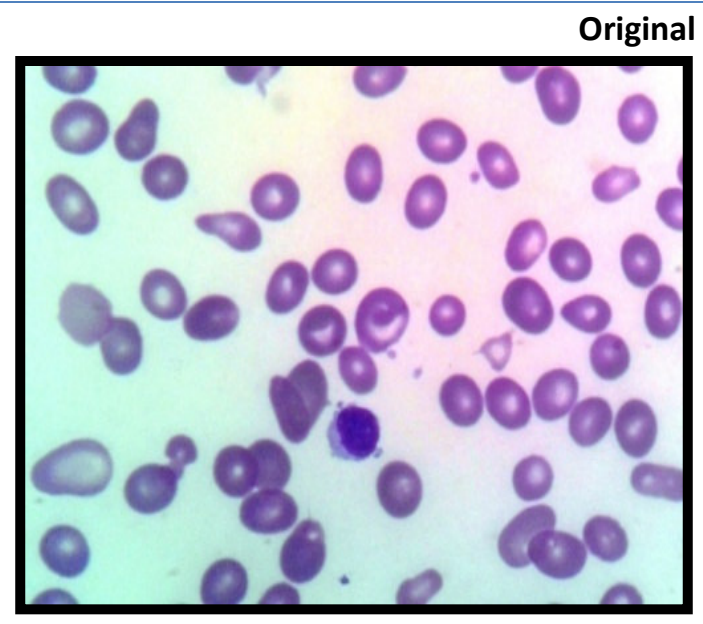

Figure 3: Macrocytic anemia: macro-ovalocytes with marked degree of anisopoikilocytosis. (field's stain, 1000x).

Vitamin B12 is a rare cause of anemia in pregnancy. It was observed only one case of macrocytic anemia (1.6\%) whereas other authors have shown higher prevalence of vitamin B12 deficiency (67\%). They have also found more number of mild to moderate anemia due to vitamin B12 deficiency as compared to severe and very severe anemia [35].

\section{Conclusion}

The present study was conducted to assess the prevalence, type and cause of anemia in pregnancy. The overall prevalence of anemia among pregnant women was higher and it indicates that anemia in pregnancy is still a major public health problem. Socio-demographic factors are the major variables which can contribute in increasing the prevalence of anemia in pregnancy. Preventing early marriages and consequent high adolescent pregnancies in India can help to improve nutritional status and better utilization of health care services among women.

Health education should be provided both to adolescent girls and pregnant women about nutrition andmake them aware about the complications of anemia during pregnancy. It is essential to take a detailed history and thorough clinical examination along with battery of investigations of all pregnant women so that anemia can be diagnosed early, thus decreasing maternal and fetal morbidity and mortality during pregnancy.

In the present study there were certain limitations, firstly; only the pregnant women were included who visited the present hospitals ANC clinic and secondly; pregnant women from surrounding rural areas were not included where prevalence of anemia and factors contributing to it may be different.

\section{What the study adds to the existing knowledge?}

Anemia is the most common disorder seen during pregnancy and can be one of the causes for maternal and child mortality and morbidity worldwide. The findings of this study can be utilized to reduce the rate of prevalence of anemia during pregnancy and measures can be taken by the health personnel to educate pregnant women on importance of anemia with more emphases on its causes and health implications on maternal and child health.

Education can be given on proper nutrition and to improve intake of iron and proteins in diet along with maintaining personal hygiene, de-worming and regular intake of iron and folic acid supplements during pregnancy which can definitely help to reduce the incidence of anemia. At rural health centre, early registration of all pregnant females with regular checkups and follow-up should be done.

A simple and cost-effective method that is peripheral blood smear examination can be performed for typing of anemia and can be utilized on regular basis so that it can help in early detection of anemia and proper treatment can be given to all pregnant women. In severe cases they can be referred to higher centre for further work up and treatment thus minimizing complications which can occur during pregnancy.

\section{Author's Contribution}

Dr. Manisha Tambekar and Dr. Evith Pereira contributed to the concept and design of the study, interpreted the data and prepared the manuscript.

Funding: Nil; Conflict of Interest: None initiated Permission from IRB: Yes

Pathology Update: Tropical Journal of Pathology \& Microbiology Available online at: www.medresearch.in 798 | P a g e 
Original Research Article

\section{References}

1. Sharma JB, Shankar M. Anaemia in pregnancy. J Int Med Sci Acad. 2010;23(4):253-260.

2. Seema BN. Prevalence of anemia among pregnant women in rural Koppal: a study from teaching hospital, Koppal, India. Int J Reprod Contracept Obstet Gynecol. 2017; 6(9):3792-3795. doi:http:// dx.doi. org/10. 18203/ 2320-1770.ijrcog20173605.

3. Olatunbosun OA, Abasiattai AM, Bassey EA, James RS, Ibanga G, Morgan A. Prevalence of Anemia among Pregnant Women at Booking in the University of Uyo Teaching Hospital, Uyo, Nigeria. Biomed Res Int, 2014. doi: $10.1155 / 2014 / 849080$.

4. Abdelgader EA., Diab TA., Kordofani AA., Abdalla SE. Haemoglobnin level, RBCs Indices and iron status in pregnant females in Sudan. Basic Res J Med Clinic Sci.2014;3(2):8-13.

5.Lokare PO, Karanjekar VD, Gattani PL, Kulkarni AP. A study of prevalence of anemia and sociodemographic factors associated with anemia among pregnant women in Aurangabad city, India. Ann Nigerian Med. 2012;6 (1): 30-34. doi: 10.4103/0331-3131. 100213

6. Vivek RG, Halappanavar AB, Vivek PR, Halki SB, Maled VS, Deshpande PS, et al. Prevalence of anemia and its epidemiological determinants in pregnant women. Al Ameen J Med Sci. 2012; 5(3):216-223.

7. Saraswathi K.S, Farhana A, Shyamala R. Der Pharmacia Lettre, 2013;5(1):146-148.

8. Rao SP, Srikanth S. Prevalence of anemia in the first trimester of pregnancy in rural population of Krishna district in Andhra Pradesh. Sch J App Med Sci. 2013;1(5):570-574.

9. Ullah I, Zahid M, Ismail KM, Shah M. Prevalence of anemia in pregnant women in district karak, Khyber Pakhtunkhwa, Pakistan. Int. J. Biosci. 2013;3(11):7783. doi- $10.12692 / \mathrm{ijb} / 3.11 .77-83$.

10. Naz Huma, Bushra Begum. Prevalence and associated risk factors of anaemia in pregnant women in a teaching hospital, Korangi Industrial Area. Pak J Surg 2013;29(2):131-133.

11. Neha YB, Wingkar KC, Joshi AG, Swati J. Assessment of severity \& types of anaemia during pregnancy in rural population in Western Maharashtra. Indian J Basic Applied Med Res. 2014;4(1):160-163
12. Vemulapalli B, Rao KK. Prevalence of Anaemia among pregnant women of rural community in Vizianagaram, north coastal Andhra Pradesh, India. Asian J Med Sci. 2014;5(2):21-25. doi: https://doi.org/ 10.3126/ajms.v5i2.5295.

13. Mahashabde P, Arora VK, Sharma S, Shahjada A, Dabhi HM. Prevalence of Anemia andits SocioDemographic Determinants in Pregnant Women: A Cross- Sectional Study in Tertiary Health Care Setup in Central India. Natl J Community Med. 2014; 5(1): 126-130.

14. Morsy N, Alhady S. Nutritional status and socioeconomic conditions influencing prevalence of anaemia in pregnant women. Int J Sci Technol Res. 2014;3 (7): 54-60.

15. Gedefaw L., Ayele A., Asres Y. and MossieA. Anemia and Associated Factors Among Pregnant Women Attending Antenatal Care Clinic in Wolayita Sodo Town, Southern Ethiopia. Ethiop J Health Sci. 2015; 25(2): 155-162.

16. Anjum A., Manzoor M., Manzoor N. and Shakir H.A., 2015. Prevalence of anemia during pregnancy in district Faisalabad, Pakistan Punjab Univ. J. Zool. 2015; 30(1):15-20.

17. Suryanarayana R, Santhuram AN, Chandrappa M, Shivajirao P, Rangappa SS. Prevalence of anemia among pregnant women in rural population of Kolar district. Int J Med Sci Public Health. 2016;5:454-458. doi: 10.5455/ijmsph.2016.2307201575.

18.Manjulatha B., Padmasri P., Prathibha T.S. Prevalence of anemia in Pregnant women in Tertiary Care Centre. IOSR-JDMS 2015; 14 (7): 91-95.

19. Mangla M., Singla D. Prevalence of anaemia among pregnant women in rural India: a longitudinal observational study. Int J Reprod Contracept Obstet Gynecol. 2016;5(10): 3500-3505.doi: http://dx.doi.org / 10. 18203/2320-1770.ijrcog20163431.

20. Siddalingappa $\mathrm{H}$, Murthy NMR, Ashok NC. Prevalence and factors associated with anaemia among pregnant women in rural Mysore, Karnataka, India. Int J Community Med Public Health 2016;3(9):2532-2537. doi: http:// dx.doi.org/ 10.18203/ 2394-6040.ijcmph 20163067. 


\section{Original Research Article}

21. Prashant D, Jaideep KC, Girija A, Mallapur MD. Prevalence of anemia among pregnant women attending antenatal clinics in rural field practice area of Jawaharlal Nehru Medical College, Belagavi, Karnataka, India. Int J Community Med Public Health. 2017; 4(2): 537-541. doi: http://dx.doi.org/10. 18203/ 2394-6040.ijcmph20170287.

22. Shah AR, Patel ND, Shah M. Hematological parameters in anemic pregnant women attending the antenatal clinic of rural teaching hospital. Innovative $\mathbf{J}$ Med Health Sci. 2012;2(5):70-73.

23. Kefiyalew et al. Anemia among pregnant women in Southeast Ethiopia: prevalence, severity and associated risk factors. BMC Research Notes. 2014; 7:771. doi: https://doi.org/10.1186/1756-0500-7-771.

24. Alene KA, Dohe AM. Prevalence of anemia and Associated factors among pregnant women in urban area of Eastern Ethiopia. Anemia, 2014. doi: http:// dx.doi.org/10.1155/2014/561567.

25. Bhise M. A study of anaemia in pregnancy and associated factors at rural area. Int $\mathrm{J}$ Rec Trends Sci Tech. 2014;10(3):543-547.

26. Rawat K, Rawat N, Mathur N, Mathur M, Chauhan $\mathrm{N}$, Kakkar R, et al. Prevalence and pattern of anemia in the second and third trimester pregnancy in Western Rajasthan. Int J Res Med Sci 2016;4(11):4797-4799. doi: 10.18203/2320-6012.ijrms20163768.

27. Bano F, Mahajan PC. Study of anaemia among pregnant women in urban areas of Kanpur. Rama Univ Med Sci 2016;2(1):1-5.
28. Pawale PP. Study of hematological parameters in anemia in pregnancy in a tertiary care hospital. MedPulse- Int Med J. 2017;4(6):761-765.

29. World Health Organization. The prevalence of anaemia in women: a tabulation of available information. $2^{\text {nd }}$ ed. Geneva: World Health Organization, 1992.

30. Kundap RP, Dadewar A, Singru S, Fernandez K. A comparative Study of Prevalence of Iron Deficiency Anemia in Antenatal Women from Urban and Rural Area of Pune, India. Nat J Community Med. 2016;7 (5): 351-354

31. Amardeep T, Shila S, Kumar S, Varma P, Surekha T. Socio-demographic determinants associated with iron deficiency anemia in pregnancy in rural population of central India. Int J Biomed Ad Res. 2015;6(12):817823. doi: https://doi.org/10.7439/ijbar.v6i12.1916.

32. Bora Gayatri, Barman Shrabani, Barman Jyotismitha (Deka). Maternal Anaemia: A Prevailing Burden In Assam,India.IOSR J Dent Med Sci.2015;14(3):42-47

33. Das S, Char D, Sarkar S, Saha TK, Biswas S. Study of hematological parameters in pregnancy. IOSR J Dent MedSci. 2013;12(1):42-44.doi:10.9790/0853-1214244.

34.Demmouche A, Lazrag A, Moulessehoul S. Prevalence of anaemia in pregnant women during the last trimester: consequense for birth weight. Eur Rev Med Pharmacol Sci. 2011;15(4):436-445.

35. Garima, Jyala N.S., Chaudhary D.A study of vitamin B12 deficiency in anemia in pregnancy. Int $\mathrm{J}$ Ad Sci Eng Technol. 2016;4(4):116-119.

\section{How to cite this article?}

Pereira E, Tambekar M. Anemia in pregnancy: a prospective study of 100 cases. Trop J Path Micro 2019;5(10):790800.doi:10.17511/jopm.2019.110.07. 